Eagles, in spite of the bird being the American national emblem. Bounties were an expensive method of controlling predators; for example, farmers in Pennsylvania may have saved only one dollar's worth of chickens for each $\$ 1205$ in bounties paid by the state.

Most members of the public viewed hawks and owls as enemies to be shot on sight. "The only good hawk is a dead hawk," people would rationalize. In Pennsylvania, so-called sportsmen thronged to specific sites along the margin of Hawk Mountain to engage in wholesale killing of most species of raptor that flew by.

Those who believe that a single person can do little to change conservation practices will be impressed by the story of Rosalie Edge, who purchased a portion of Hawk Mountain that included the shooting sites. She then hired a warden to police the land. Against intense local opposition, the land was posted and hunters were deprived of the best place in all Pennsylvania to shoot the state-bountied Northern Goshawk. Because of Rosalie's vision and determination, Hawk Mountain has become a major educational and conservation center, increasing in importance each year.

This book lists each of the growing number of raptor monitoring sites, more than one hundred, where keen volunteers flock to help. The greatest effort is given to the fall migration. The "Veracruz River of Raptors" has posted numbers as high as 5.26 million in a single fall migration. There, the top four species are the Turkey Vulture, just shy of 2 million, Broadwinged Hawk at 1.92 million, Swainson's Hawks up to 915000 and Mississippi Kites an impressive 155 000. A million Turkey Vultures have also been counted at Kekoldi in Costa Rica.

This book is replete with maps, graphs and tables. Seven excellent maps, for example, together demonstrate the impressive band recoveries for Sharpshinned Hawks. Movements of many other raptors, however, are less well known and knowledge of their population levels is limited.

Raptor monitoring in Canada receives appropriate attention. Since hawks only come together in increasing numbers as they move south, they do not coalesce into large flocks in some parts of Canada. An exception are the 107000 Broad-winged Hawks counted during the 1996 fall migration at Holiday Beach near Windsor, Ontario. There are three sites in Quebec where over 1000 of one raptor species may be counted in a single day. Ontario has ten sites, including Hawk Cliff, and there are two each in Manitoba and British Columbia. In Alberta, at Windy Point, manned since 1967, over one thousand each of Sharp-shinned Hawks and Golden Eagles may be counted passing by. At nearby Mount Lorette, the Golden Eagle count can reach the neighbourhood of 4700. Canadian contributors to the book include David Hussell, a pioneer in developing the Raptor Population Index, a new counting method that aims for more consistency in raptor counting. Erica Dunn is the lead author for the Watchsite Methods chapter.

While insect-eating and ground-nesting birds continue to decline across North America, there is more good news than bad from the raptor front. While Northern Harrier and American Kestrel are diminishing at many sites, Swainson's Hawks, Bald Eagles, Peregrine Falcons and Turkey Vultures are generally increasing. The ground-nesting harrier is at risk from many predators, but it makes less sense that the kestrel, with relatively safer nest sites in boxes and cavities, should also be in decline. The impact of habitat changes, weather and food availability is being studied for many species.

There are minor defects in this compendium. There is a misleading absence of "Diurnal" before "Birds of Prey" in the title. Owls are not included, although the four-year cyclical irruptions of the Great Gray Owl and Northern Hawk-Owl can be dramatic. We are told in one sentence that irruptive migrations of the Northern Goshawk "occur periodically in years of low prey availability" but we are not told that this is part of a general 10-year cycle involving hare, lynx and Great Horned Owls. In the section on types of migration, "irruptive migration" should have been added to "loop," "altitudinal" and "leap-frog" migrations. The book lacks a detailed index.

Despite these minor flaws, this book belongs in the library of every raptor enthusiast and in every university and college library. Some chapters warrant reading in their entirety and others are excellent reference material. Anyone with the slightest interest in the rapidly growing field of hawk monitoring should read the salient chapters, and become aware of the contents of the others.

C. STUART Houston

863 University Drive, Saskatoon, Saskatchewan S7N 0J8 Canada

\title{
Owls of the United States and Canada: A Complete Guide to Their Biology and Behavior
}

By Wayne Lynch. 2008. University of British Columbia Press, 6344 Memorial Road, Vancouver, British Columbia V6T 1Z2. 242 pages 39.95 CAD Cloth.

Wayne Lynch is an accomplished photographer and writer, I had no expectations that his newest book would represent anything less than the standard for which he is known.
The list of "things I would do differently" is quite small, but worth mentioning. The title, A complete guide... strikes me as being somewhat pompous... we know so much about owls that offering up a single tome as being somehow complete is a bit much. Then there's the tank of information yet to be discovered! Secondly, I'd be willing to bet that the vast 
majority of research that was done by the original biologists was reported in metric. However, all of that was converted to imperial, rounded off and reported as such; parenthetically, the imperial values were reconverted and oft-reported as inappropriately-accurate metric values again, which muddles the original values and makes the reading stumbly. Both the birding and ornithological literature have long used a convention of capitalizing bird names; this avoids some potential confusion when, for instance, referring to "the Northern Hawk Owl" (the species) versus "the northern hawk owl" (the hawk owl found more northerly than others). I find newspapers reticent to adopt this standard, but there's no reason for this book to have done so. Those well-read in bird literature will do mental hiccups frequently while reading this book.

Chapters often start with a journal entry or description of an individual encounter with owls that beautifully sets up the chapter's theme. By doing this, Lynch maintains a personal connection with readers, which then encourages them to continue reading the morematter-of-fact, but still very well-written material later.

There is a nice 10-page identification guide to the owls, with range maps and a synopsis of information such as habitat preferences, life span, diet and status. Although the text is good, the maps are deceptive. Unlike most field guides, the maps here use only one colour to report the species' ranges. And if you didn't know any better, you'd think the Snowy Owl bred everywhere in Canada, and into the northern tier of the United States (which it doesn't). Johnsgard's book on North American Owls does more justice to the ranges.

The rest of the book is written topic-by-topic, much like Duncan's Owls of the World. Other owl books, like Mikkola's Owls of Europe, take a more speciesby-species account, with a few introductory chapters

\section{Owls of North America}

By Frances Backhouse. 2008. Firefly Books Ltd, 66 Leek Crescent, Richmond Hill Ontario L4B 1H1. 215 pages, 34.95 CAD Cloth.

Owls of North America, by Canadian writer Frances Backhouse, is a beautiful book - literally. The first thing I did when it came into my possession was to look at the photographs. A Great Horned Owl silhouetted against a sunset. A close-up of the same species' primary flight feathers. An Elf Owl delivering a cricket to its cactus nest. The large eyespots on the back of a Northern Pygmy-Owl's head. Great Gray Owls engaging in mutual preening. A young Long-eared Owl hanging upside down from a twig. A Short-Eared Owl stretching its leg as a warm-up to hunting.

I would have been thrilled with the book for the photographs alone. When I started reading, it got even better. Eight chapters discuss topics covering a wide range: owl and human relations, owl family groupings, life trajectories, feeding habits, communication, adaptations for nocturnal life, and more. Almost 80 pages on topics like food, anatomy, movements, etc. I don't think one format can be said to be better than the other in general, each excels for different reasons. The approach adopted by Lynch makes for a more coffee-table friendly book; different species can be depicted in any one chapter, making comparisons among, for instance, insectivores to carnivores, readily apparent.

Throughout the book are sidebars containing synopses of topics related to the chapters' contents. I've always liked this approach as it allows for information that is otherwise not readily incorporable to be presented. In this book, the topics range from the $\mathrm{pH}$ scale (used to discuss digestion) to brooding behaviour.

Finally...the photographs. Dr. Lynch is perhaps bestknown for his stunning photography. There are some awe-inspiring habitat shots, and double-page spreads that leave the reader with a sense that "I must visit that place." The shots of the owls themselves rate with the best I've ever seen and include depictions of some behaviours that are not frequently seen. Not to diminish the writing at all, but the photographs really make this book what it is.

\section{Literature Cited}

Duncan, J. Owls of the World: Their Lives, Behavior, and Survival. 2003. Firefly Books, 66 Leek Crescent, Richmond Hill Ontario L4B 1H1 319 pages

Johnsgard, P. 1988. North American Owls: Biology and Natural History. Smithsonian Institution Press, Washington. 298 pages

Mikkola, H. 1983. Owls of Europe. Buteo Books, Vermillion. 397 pages

RANDY LAUFF

St. Francis Xavier University, Antigonish, Nova Scotia B2G 2W5 Canada

are devoted to relatively comprehensive species profiles that provide photographs, maps, and details on appearance, voice, activity, roosting, distribution, habitat, feeding, breeding, migration, and conservation. A glossary and bibliography complete the information offerings.

The book brought alive owl species I was only vaguely aware of. The Elf Owl of the southwest, the world's smallest owl, which feeds mainly on insects. The Flammulated Owl of the west, also an insect-eater, with ventriloqual abilities that make singers difficult to locate. The Vermiculated Screech-Owl of Mexico, Central and South America, which sings like a toad.

The book also deepened my understanding of owls which are more familiar to me. The Great Horned Owl, that consumes a greater diversity of prey - from grasshoppers to great blue herons - than any other North American owl. The Great Gray Owl, which is benefiting from nesting platforms; one study revealed that nesting success was higher on platforms than natural nest sites. 